\title{
$\mathrm{T} 2$ 부위의 척주세움근면차단 후 국소마취제 확산에 대한 Magnetic Resonance Imaging 영상
}

김문규

순천향대학교 의과대학 서울병원 마취통증의학과

\section{Magnetic Resonance Imaging Images of the Local Anesthetic Spreading after Erector Spinae Plane Block at T2 Level}

\section{Mun Gyu Kim}

Department of Anesthesiology and Pain Medicine, Soonchunhyang University Seoul Hospital, Soonchunhyang University College of Medicine, Seoul, Korea

It has been reported that erector spinae plane block (ESPB), which was performed at the mid-thoracic level, can be effective for the visceral and somatic pain of the thoracic region. The magnetic resonance imaging (MRI) images showed the diffusion of the contrast medium into the transforaminal and epidural spaces after ESPB, and these MRI findings helped to understand the mechanism of the analgesic effect. There have also been reports that ESPB at the upper thoracic level can reduce the pain of the shoulder and upper extremities. However, no MRI images have been reported to support the mechanism of analgesic effect in the cervical region. We report for the first time the MRI images of local anesthetic spread after ESPB at the T2 level.

Keywords: Nerve block; Erector spinae plane block; Cervical nerve; Magnetic resonance imaging

\section{서 론}

척주세움근면차단(erector spinae plane block, ESPB)은 2016년 Forero 등[1]이 흥부의 신경병성 통증을 가진 환자에서 시행하여 통증 감소효과를 처음으로 보고한 뒤 흥추와 요추부위에서 통증 조절에 활용된 많은 연구들이 있었다[2]. 전통적인 방법인 척추주 위차단(paravertebral block)이나 경막외 신경차단(epidural block) 과는 달리 ESPB의 작용기전은 모호할 수 있으나 cadaver 연구와 magnetic resonance imaging (MRI), computed tomography (CT) 를 통한 영상 연구에서 신경축차단(neuraxial block)과 유사한 효 과가 나타날 수 있음이 보고되었다[3-5].

이에 반해 경추부위에서의 ESPB 또는 고위 흥추부위에서 경신 경(cervical nerve)을 목표로 시행되는 ESPB에 대한 무작위 대조군 연구가 아직은 드물고, 어깨와 상지의 진통효과에 대한 증례 위주
로 보고되고 있다. 또한 이러한 진통효과의 기전을 입증할 수 있는 cadaver 연구와 CT 영상은 보고되었지만 MRI 영상은 보고된 바 없다. 일반적으로 MRI는 CT보다 공간해상력이 높고 연조직의 구 별이 좀 더 명확하기 때문에 국소마취제의 확산 경로를 좀 더 정확 히 확인할 수 있다.

본 저자는 경추간공 협착이 있는 환자의 진단을 위한 MRI 영상 에서 ESPB 시행 후 국소마취제의 확산경로를 우연히 확인할 수 있 었기에 이에 대한 영상과 함께 최근 문헌들에 대해 고찰해 보았다.

\section{증 례}

44세 남자 환자가 6개월 전부터 발생한 우측 뒷목과 어깨 통증 이 10 일 전부터 악화되어 내원하였다. 환자는 내원 3 일 전 타 병원 X-ray 검사에서 디스크 간격이 좁아졌다고 들었다 하였고, 직업은 
건설업에 종사 중이고 매일 소주 1 병의 음주력과 20 갑 년의 흡연력 이 있었다. 증상은 철봉을 이용한 운동 시 예전보다 힘을 잘 못 준다 고 하였고, 우측 뒷목부터 어깨 뒤쪽이 지속적으로 결린다고 표현 하였으며, 내원 당일 숫자등급척도(Numeric Rating Scale, NRS; 0, 통증이 없는 상태; 10 , 가장 심한 통증)는 6점이었다. 이학적 검사에 서 우측 elbow flexion 시 grade 4 정도로 근력 약화가 관찰되었고 spurling test 양성 소견이 관찰되었다. 환자에게 MRI 검사의 필요 성에 대해 설명하였고 통증 감소를 위해 ESPB 시술을 권유하였으 며 환자에게 시술에 대한 설명 및 동의를 받고 시행하였다. ESPB는 복와위에서 시행하였으며 linear probe (5-15 MHz)로 T2 우측 횡 돌기를 확인하고 in plane 방법으로 $22 \mathrm{G}$ quincke needle 끝이 횡돌 기에 닿은 후 $0.2 \%$ ropivacaine $25 \mathrm{~mL}$ 를 주입하였다. 환자는 $\mathrm{ESPB}$
후 $10 \%$ 정도만 통증이 감소하였다고 하였고, pregabalin $150 \mathrm{mg}$, tramadol $100 \mathrm{mg}$, dexibuprofen $600 \mathrm{mg}$, oxycodone $10 \mathrm{mg}$ 을 하루 용량으로 처방받았다. 그리고 3일 후 경추부 MRI 검사를 예약하고 귀가하였다.

4일 후 약속된 날짜에 환자는 다시 내원하였다. 환자는 증상 호 전이 미약하다고 하였고 지속적인 통증이 있었다고 하였다. MRI 촬영은 지난번 ESPB 시행한 후 귀가 전에 다른 환자의 MRI 예약이 취소되어 지난번 내원 당일에 촬영하였다고 하였다. 의무기록 시간 으로 확인해 보면 ESPB 시행 2시간 후에 촬영한 것으로 확인되었 다. MRI에서 양측 신경공협착(bilateral neural foraminal stenosis, C4-5 and C5-6) 소견이 관찰되었고(Fig. 1), C3-T3 부위의 우측 척 주세움근을 따라서 증가된 신호 강도가 관찰되었다(Fig. 2). C6-7
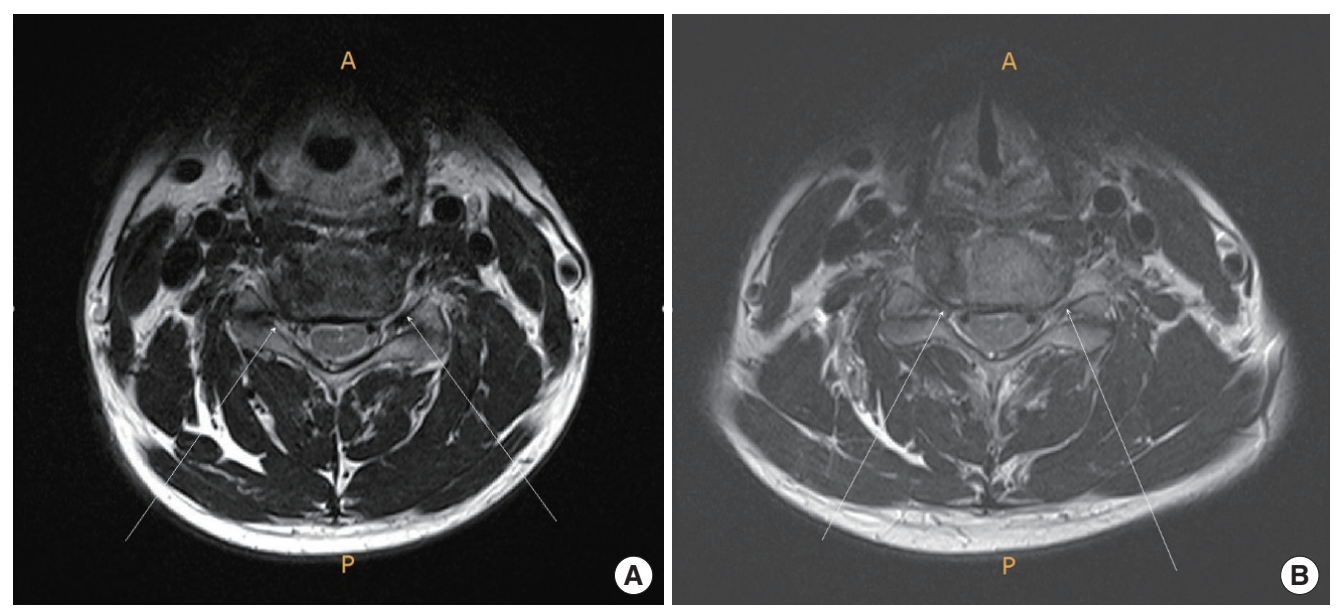

Fig. 1. Magnetic resonance imaging images of cervical spine. (A) Bilateral neural foraminal stenosis in C4-5. (B) Bilateral neural foraminal stenosis in C5-6 (more severe in right side).
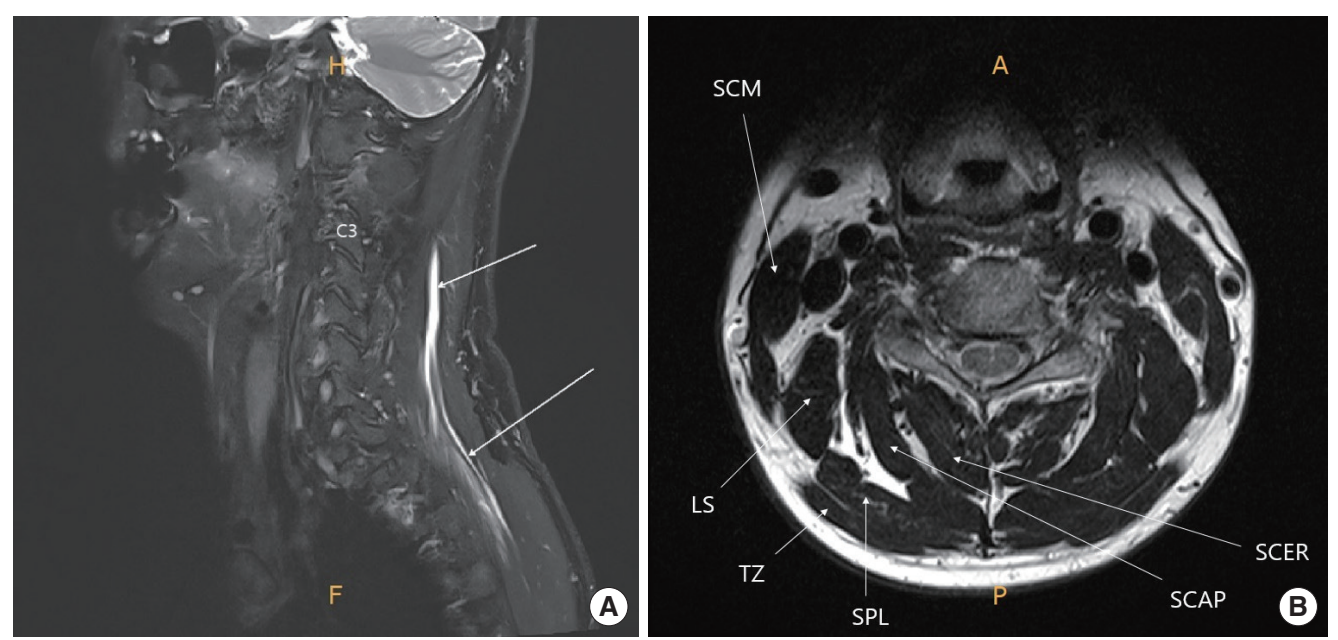

Fig. 2. T2-weighted sagittal and axial images. (A) The spreading of local anesthetic is seen in right erector spinae muscle from C3 to T3. (B) The spreading of local anesthetic is seen between splenius capitis and semispinalis capitis muscles and near the spinal nerve root at C4-5 level. SCM, sternocleidomastoid; LS, levator scapulae; TZ, trapezius; SPL, splenius capitis; SCAP, semispinalis capitis; SCER, semispinalis cervicis. 
부위에서 dexamethasone $5 \mathrm{mg}$ 과 lidocaine $20 \mathrm{mg}$ 을 생리식염수 에 혼합하여 경추 경막외 신경차단술을 시행하였다. 환자는 시술 후 50\% 이상 통증 감소를 확인하고 귀가하였으며, 이때 환자에게 출판을 위한 MRI 영상 및 의무기록의 사용에 대한 동의를 받았다.

\section{고 찰}

$\mathrm{ESPB}$ 는 흥추부위 통증조절을 위해 $\mathrm{T} 5$ 부위에서 처음 시행되었 으나 점차 그 부위를 확장하여 흥추부위뿐만 아니라 요추부위에 서도 많은 연구들이 진행되었다. 흉추부위에서의 $\mathrm{ESPB}$ 는 유방절 제술과 비디오보조흥강경수술(video-assisted thoracoscopic surgery)에서 수술 후 진통효과가 입증되었고, 척추주위차단과 비교 했을 때 유사한 진통효과가 있는 것으로 보고되었다[6]. 또한 요추 부위에서의 $\mathrm{ESPB}$ 는 고관절수술과 척추수술, 소아 복부수술 등에 서 수술 후 진통효과가 보고된 바 있다[5]. 그리고 이러한 임상적 효 과를 뒷받침할 수 있는 국소마취제의 확산과 관련된 연구들도 증 가하고 있다.

흥추부위에서 시행된 ESPB의 효과가 체성통증뿐만 아니라 내 장성 통증에도 효과가 있을 것으로 기대되는 MRI 영상이 보고된 바 있다. Schwartzmann 등[4,7]은 T10 횡돌기에서 $30 \mathrm{~mL}$ 용량으로 ESPB 시행 후 늑간강(intercostal space)뿐만 아니라 척추주위공간 (paravertebral space)과 경막외공간(epidural space)까지 조영제가 확산되는 것을 확인하였다. 다만, 경막외공간으로의 확산이 T5-L2 의 넓은 범위로 확산되는 경우는 6 명의 환자 중 1 명에서만 확인되 었고, 나머지 5 명의 환자에서는 경막외공간에서 조영제 신호 강도 가 아주 미약하거나 발견되지 않았다. 또한 Celik 등[8]은 L4 부위 에서 $40 \mathrm{~mL}$ 용량으로 ESPB 시행 후 L1-5까지 신경공과 경막외공 간에서 조영제가 관찰되었다고 하였고, 고용량의 약제 사용 시 경 추간공 접근 경막외신경차단술(transforaminal epidural block)과 유사한 효과가 있을 수 있음을 소개하였다.

경신경(cervical nerve)을 목표로 시행된 ESPB에 대한 연구들은 아직 많지 않지만 최근 T2 부위에서 시행된 ESPB가 어깨수술 후 통증조절에 효과가 있었다는 결과가 보고된 바 있다[9]. 그리고 국 소마취제의 확산에 대한 cadaver 연구에서 Elsharkawy 등[10]은 $\mathrm{C} 6$ 또는 $\mathrm{C} 7$ 횡돌기에서 $20 \mathrm{~mL}$ 용량을 투여하였을 때 횡돌기 앞쪽 으로는 C4-T1의 신경근이 염색되었고, 횡돌기 뒤쪽으로는 승모근 (trapezius)과 흥쇄유돌근(sternocleidomastoid)의 기시부(origin) 에서 마름모근(rhomboid)과 늑간근(intercostal) 사이의 조직면 (tissue plane)까지 염색되었다고 하였다. 또한 동측의 횡격막 신경 도 10 명 중 3 명에서 염색되었다고 보고하였다.

본 증례의 경우 MRI 가로영상(axial image)에서 국소마취제가 목반가시근(semispinalis cervicis)과 두판상근(splenius capitis)의 사이로 확산되어 신경근 주위까지 도달하는 것을 볼 수 있었고, 앞 뒤세로영상(sagittal image)에서는 C3에서 T3까지 척주세움근에 서 확산되는 것을 확인할 수 있었다. 하지만 추간공과 경막외공간 으로의 확산은 명확히 발견할 수 없었고 이러한 이유로 추간공 협 착으로 인한 통증에 $\mathrm{ESPB}$ 의 효과가 미미했을 것으로 추정된다. 다 만, 이전 연구들은 모두 전향적 연구이기 때문에 조영제를 사용한 반면, 본 증례에서는 조영제 사용이 없었기 때문에 경막외강으로 의 국소마취제 확산이 적을 경우 정확히 확인되지 않을 가능성이 있다. 그리고 본 증례에서는 $25 \mathrm{~mL}$ 의 용량을 사용하였는데, 흥추 와 요추부위에서 고용량 $(30-40 \mathrm{~mL})$ 의 국소마취제를 사용하여 ESPB 후 경막외공간까지 확산되었다는 점을 고려하면 용량을 증 가시킬 경우에 대한 추가 연구가 필요할 것으로 생각된다.

결론적으로, $\mathrm{T} 2$ 부위에서의 $\mathrm{ESPB}$ 시행 시 척주세움근면을 따라 신경근 주위까지 국소마취제가 확산될 수 있으며, 본 증례처럼 통 증의 원인이 신경근보다 근위에 있는 경우에는 $\mathrm{ESPB}$ 의 효과가 제 한적일 수 있다. 앞으로 조영제를 이용한 MRI 영상에 대한 추가 연 구와 어깨를 포함한 상지의 통증 원인에 따른 $\mathrm{ESPB}$ 의 효과에 대한 연구들이 더 요구된다.

\section{REFERENCES}

1. Forero M, Adhikary SD, Lopez H, Tsui C, Chin KJ. The erector spinae plane block: a novel analgesic technique in thoracic neuropathic pain. Reg Anesth Pain Med 2016;41:621-7.

2. Tsui BCH, Fonseca A, Munshey F, McFadyen G, Caruso TJ. The erector spinae plane (ESP) block: a pooled review of 242 cases. J Clin Anesth 2019; 53:29-34.

3. Aponte A, Sala-Blanch X, Prats-Galino A, Masdeu J, Moreno LA, Sermeus LA. Anatomical evaluation of the extent of spread in the erector spinae plane block: a cadaveric study. Can J Anaesth 2019;66:886-93.

4. Schwartzmann A, Peng P, Maciel MA, Alcarraz P, Gonzalez X, Forero M. A magnetic resonance imaging study of local anesthetic spread in patients receiving an erector spinae plane block. Can J Anaesth 2020;67:942-8.

5. Tulgar S, Aydin ME, Ahiskalioglu A, De Cassai A, Gurkan Y. Anesthetic techniques: focus on lumbar erector spinae plane block. Local Reg Anesth 2020;13:121-33.

6. Huang W, Wang W, Xie W, Chen Z, Liu Y. Erector spinae plane block for postoperative analgesia in breast and thoracic surgery: a systematic review and meta-analysis. J Clin Anesth 2020;66:109900.

7. Schwartzmann A, Peng P, Maciel MA, Forero M. Mechanism of the erector spinae plane block: insights from a magnetic resonance imaging study. Can J Anaesth 2018;65:1165-6.

8. Celik M, Tulgar S, Ahiskalioglu A, Alper F. Is high volume lumbar erector spinae plane block an alternative to transforaminal epidural injection? Evaluation with MRI. Reg Anesth Pain Med 2019 Apr 16 [Epub]. https:// doi.org/10.1136/rapm-2019-100514.

9. Ciftci B, Ekinci M, Golboyu BE, Kapukaya F, Atalay YO, Kuyucu E, et al. High thoracic erector spinae plane block for arthroscopic shoulder surgery: a randomized prospective double-blind study. Pain Med 2021;22: 776-83.

10. Elsharkawy H, Ince I, Hamadnalla H, Drake RL, Tsui BCH. Cervical erector spinae plane block: a cadaver study. Reg Anesth Pain Med 2020; 45:552-6. 